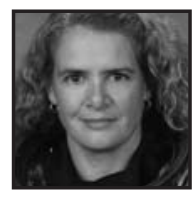

\title{
Taking Charge of Our Educational Journey
}

\author{
Julie Payette
}

\begin{abstract}
In this interview Julie Payette discusses the role education has had in her life and in achieving her childhood dream of becoming an astronaut. She shares her experience of attending the United World College of the Atlantic as a teenager and her discovery of the value of learning languages. Julie speaks on the importance of parental support in encouraging children to pursue higher education and expresses some thoughts on teacher preparation. She also comments on how stereotypes and stigmas can still prevent girls from choosing to become scientists. Finally, Julie gives us a glimpse of what it feels like to contemplate planet earth from the window of a space shuttle.
\end{abstract}

Julie, you were born in Montreal and are a Canadian icon, many students look to you as a model - where did your passion for this career come from and what educational moments contributed to this?

was very fortunate to grow up in a city, in a country that gave me a lot of opportunities. I'Il never forget being in primary school and watching TV with my fellow students and there on the screen were people walking on the moon. It was the beginning of the 1970s and the Americans had the Apollo missions to the moon and astronauts were out there, in spacesuits and with a lunar rover and going around on the moon and I thought that was the greatest thing and I wanted to do the same thing. I just wanted to be an astronaut too, go in the rocket and explore. And when I grew up I realized there was no school or place that would allow me to do this, so I decided to pursue a career in engineering with the idea that if ever, one day, there 
was an opportunity to go to space, then maybe at least I would have the right qualifications. I made a lot of my decisions with that little idea in mind, not thinking I would actually achieve it, but if you don't try you never know.

Generally, what do you consider to be the fundamental or more important dimensions of education?

To me, getting an education is key. There are a number of things that we cannot control. We don't control where we are born, what we look like, what our genes are ... As well, we cannot choose the socioeconomic setting in which we are raised. However, as individuals, in this country, we have complete control on our life decisions about whether or not to get an education and how we're going to go about it. If we have to work, we can still get a full education and that is the key for making future decisions in our lives. Education is the foundation for being able to choose for oneself and for being fulfilled as a person. Then you can exert your own choice of career, profession or trade, which is an amazing feeling. We have to start early though because it takes time to get an education and we have to persevere at it, because it doesn't come over just a one- or two-month effort. And once we get some credentials by receiving our education we can grow from that, we can continue, we can then contribute to society. To me it's absolutely fundamental and I always encourage young persons to view education as their tool, as their asset, as some precious jewel in their treasure chest, and to nurture it.

Looking back on your many and varied educational experiences, what changes would you suggest for education?

At the age of sixteen I received an opportunity to go and study at an international college in South Wales, it was called Atlantic College, it is a United World College. There, students came from all over the world to study in the International Baccalaureate program. When I arrived in Wales, I was a teenager. I came from Montreal, my mother tongue was French, and I had started to learn English in fourth grade. My English was okay but I did not speak any other language. And then I noticed that some of the other students at the school spoke many different languages, mainly because they were exposed to them at a very early age. Later in life, through reading and listening to conferences about this particular topic, it became clear that we learn languages more easily when very young than later on in life. I was wondering why we don't make it so that we learn languages at a time when our brain 
will carve the neural paths necessary to transfer data between the language centres of the brain. So that is one thing I would emphasize as much as possible in early education. I live in the United States right now and people don't usually speak other languages and it's sometimes an impairment. Languages are a communication tool:they allow people to talk to each other, to communicate information, to share. And the more you speak, the more languages that is, well the better off you are, so let's get an early start on this.

Statistics show that still young girls do not choose to study sciences as often as they might. How do you think that this could be changed?

People laugh when I make the suggestion that part of the reason that young girls often shy away from science and mathematics in particular, usually turning their back on it at the end of high school, beginning of college, has to do with the aura around it. It seems like science is not for them. There is an idea that science is difficult-it's not. There's also an idea that it's not really cool to live and work in a lab. There's a stigma and some stereotypes about what a scientist looks like and how much fun they are socially, and so on and so forth. And there are other stigmas about engineers. I'm always thinking, gosh, we have all these programs on TV that people watch - those TV programs with doctors and lawyers and politicians and there is very rarely any of those programs where the principal actor or the hero of the program is an engineer or a physicist or chemist or zoologist, something like that. I believe this is partly due to the stereotypes being perpetuated, the lack of role models as well asand this has been statistically proven by those who have done research on it-the lack of encouragement from the student's inner circle. All too often, female student declarations of "well I'd like to study mathematics," are not necessarily positively received by others ... it seems to the people around them not quite the right pathand the students end up feeling discouraged. So if we could portray careers in the sciences as a natural route for young women, or even have TV programs featuring heroes that are scientists, then that would help, but of course that's a little utopian.

If parents want their children to pursue higher education what would your advice be to them?

I don't know if I have advice for anybody but I certainly have suggestions, some of which I took from my parents. Trying a lot of different things when you are a child will allow you to choose a path-a path that you like and that will challenge and bring 
out the best in you. It's much easier to put effort in a path of studies that one likes than in a path that one doesn't like and didn't choose. So diversity at an early age, exposure to different things will most of the time make people curious and then help them decide on what they want to do.I think encouragement is important of course, every single step of the way, encouragement to do better, encouragement to look for answers, to be curious and to excel. And that also takes effort and the encouragement to really try. An education doesn't come free and doesn't come without effort. It is something that pays off down the road but one needs to work at it, and parental encouragement makes a big difference here.

\section{What educational suggestions would you have for policymakers?}

Clearly education has to be accessible to all. We have to tend to students who have special needs and to students who are gifted. We have to tend to adult immigrants who come to Canada and need to learn another language or a particular trade. We also have to make sure that everybody can read, write and count because today it is impossible to function without these basic tools. So that is, of course, the main responsibility of the lawmakers and decision makers. Interestingly, some countries have a very different way of teaching the teachers, of preparing, in the educational faculties, those that will become teachers at primary school and high school in particular. In some European countries, Great Britain for example, there is a particular training for teachers of science and mathematics, and these individuals usually come from these disciplines. So to be a teacher of math in eighth grade or ninth grade you have to have a background in mathematics and science. It has been found that this helps a lot with retention and interest because of the facility with which the teacher can tackle the subject. Mathematics is a very specific subject and it is hard to teach and a lot of people get discouraged if it is presented in a dogmatic way, but it is a lot of fun and people who have a mathematics background often do a very good job. So, changing perhaps the way we teach teachers by having people that are more specifically trained for specific subjects.

Based on your wealth of experience, what changes are needed to make the best possible world for all children?

The key it seems for the welfare of children is a stable environment, one free of war and in which they can eat and have access to water and education, and so on. In North America we don't appreciate how very privileged we are, so we don't know 
what it is to live in a country that is ravaged by war, where people will fight openly and will take from each other, or where the circumstances of poverty and settlement mean that they have to think about just feeding themselves all day. If we could distribute the wealth better, that would be a good start; if we could get along better, it would also be an important start, and respect each other's opinion and be tolerant. I think we're still a long way from that but we have to strive toward making it a better world and for that to happen we all have to share the wealth.

We all wonder about space and about the adventures that you have in space, is it possible to describe one such adventure for our audience?

Perhaps the most important reason why people want to be in space, to fly in space, is to explore, to be able to float in weightlessness, but it's first and foremost to be able to contemplate the planet from above. And it's an extraordinary experience. What a privilege to be able to float to a window inside the space shuttle or the international space station and then to look back down, and see this marvel of blue, white and darker continents in the vastness of space. It is absolutely magnificent. It's better than any movie or television. You can stay there and see the earth pass by for hours and hours at a time, if we only had time. We only do it a few minutes at a time, but every single opportunity astronauts have to go to the window and look at the planet, they take it. It's a marvellous sight, but it's also home. It's the only place we have, the only place we can live, so far in the entire universe, and it's the place we return to, planet earth. 


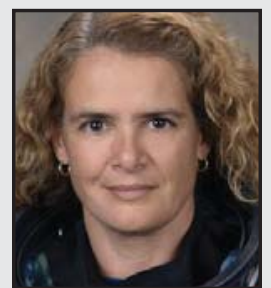

Julie Payette currently works at Mission Control Center in Houston as a CAPCOM (Spacecraft Communicator) and is responsible for all communications between ground controllers and in-flight astronauts. Prior to this she held positions at IBM Research Laboratory in Switzerland and at BellNorthern Research in Montreal.

In 1992 she was selected from 5330 applicants to become an astronaut for the Canadian Space Agency. From May 27 to June 6, 1999 she flew on Space Shuttle Discovery serving as a mission specialist and oversaw the Station systems, supervised the space walk and operated the Canadarm robotic arm. Her second mission was aboard the Space Shuttle Endeavour, from July 15 to 31,2009 , where she served as the flight engineer and lead robotics operator. She was in space a total of 9 and 16 days, respectively, for these two missions.

LINKTO:

www.asc-csa.gc.ca/eng/default.asp 